\title{
Comparative Analysis of the Tax Burden on Car Ownership and Car Use in the EU Countries and Russia
}

\author{
Igor Mayburov \\ Professor, Ural Federal University \\ named after the first President of Russia B.N. Yeltsin, \\ Far Eastern Federal University \\ Yulia Leontyeva \\ Associated Professor, Ural Federal University \\ named after the first President of Russia B.N. Yeltsin
}

\section{Doi:10.5901/mjss.2017.v8n2p9}

\section{Abstract}

The purpose of this article is to compare the tax burden on car owners and car users in the countries of Europe and in Russia and to use the findings for identifying areas of improvement in the system of fiscal instruments under the present conditions of transport development. The article examines the European experience in the construction of fixed and variable transport taxes to regulate the behavior of the car owners. The theoretical background collection of taxes for the use of a car is considered. The article looks the size of fixed taxes in different countries depends on the technical characteristics of the car that determine its capability to have a negative impact on the road network and environmental factors. A conclusion is made that in Russia, the system of transport taxes lacks logic. The level of fixed taxes that is rather higher for Russia generates two effects: it hinders the growth of car ownership and preserves the negative structure of the car fleet. The low level of variable taxes (fuel tax and tolls) encourages the intense use of passenger cars. The approach will spur further growth of car ownership rates in Russia, making people car dependent. A reform of variable transport taxes is needed to regularly increase them. Such an increase should also be accomplished by regularly increasing fuel excise duties and introducing congestion charges and toll charges on more roads, bridges, tunnels, and conservation areas.

Keywords: transport taxation, fixed transport tax, variable transport tax.

\section{Introduction}

The relevance of the subject of the study stems from a global trend towards growing population mobility and cargo flows amid limited infrastructure (road networks and environmental factors) because of higher car ownership rates. That calls for limiting the growth of the number of cars owned by the population and ensuing negative effects (road congestion, road accidents, environmental pollution) while maintaining and even spurring mobility and cargo flows (Vuchic, 1999). The experience gained by European countries shows that fiscal instruments are commonly used for regulating car ownership rates, but the effectiveness of the solution varies greatly from country to country (Levinson, 2010). Some European countries have managed to cap the growth in car ownership rates and the use of privately owned cars. At the same time, the countries have been able to keep people satisfied with the mobility opportunities and the comfort level offered by national transportation systems by prioritizing the development of public transport and improving the quality of its services (Litman, 2009).

European countries are already past the peak of mass car ownership and have learnt how to control the process. In Russia, however, public transport was the main means of transportation for passengers before the 1990s. There were only 50 automobiles per 1,000 people. At that time car ownership started to take off rapidly. At the present time, there are 300 cars per 1,000 people, but in some regions of Russia the rate might be as high as 500 cars per 1,000 people (Europe in figures, 2016). Meanwhile, public transport has been stagnating. The rapid growth in car ownership increases public mobility in Russia, first and foremost because more people own and drive cars, thus further aggravating the problems of 
traffic congestion, road accidents, low road density, a lack of parking space in urban areas, the negative impact on public health etc. In general, the development of Russia's road network is seriously lagging behind that in European countries, which encourages the application of car ownership regulation practices employed by the countries of Europe. It therefore makes sense to academically analyze and study the best European practices in the field of transport regulation in order to work out recommendations for improving transport-related fiscal instruments in Russia.

The purpose of this article is to compare the tax burden on car owners and car users in the countries of Europe and in Russia and to use the findings for identifying areas of improvement in the system of fiscal instruments under the present conditions of transport development.

\section{Literature}

Modern transportation systems give rise to various distortions that all too often make the operation of the transportation system economically ineffective. For example, a large part of costs associated with the use of privately owned cars are fixed ones that do not depend on the intensity of car use (Spending on Transport Infrastructure, 2013). This makes it economically ineffective to increase public mobility by means of public transport. Car owners might opt not to use their vehicles if they are faced with additional costs per trip that change directly as the intensity of car use (Litman, 2009).

Discouraging the use of private cars in favor of public transport should be implemented by introducing a set of monetary measures that increase the costs incurred by the car owner when he or she travels by car and that make car use less appealing an option. The travel behavior of an individual will be the derivative of the price of the planned trip. Apart from considering the price, the individual will make his or her choice by taking into account such factors as time and convenience (Vuchic, 1999).

The price of the planned trip is the key factor driving the choice, so taxes and levies imposed on the trip will have the biggest effect on changing the travel behavior of car owners (De Borger \& Mayeres, 2007).

Taxes and other mandatory fees associated with transport operation are, therefore, an instrument for fixing market distortions (Deryck, 1998).

Fiscal instruments that are aimed at regulating the use of privately owned cars, offsetting market disproportions and implementing necessary reforms have been studied in numerous works by European and American researcher (Baumol, 1972).

Members of École Nationale des Ponts et Chaussées were pioneers in the issue of substantiating the size of mandatory transport fares. Representatives of the school (Vauban, J. Dupuit, M. Allais et al.) defined a tax as the price of public services that is set in terms of the marginal utility theory. According to them, the tax (or the toll) is an instrument of collecting consumer surplus that contributes to the funding of public infrastructure, while demand for trips is a function of the size of the charge paid (Russo \& other, 2015).

The growing impacts of automobile use led to the emergence of new methodological approaches to determining the size of transport taxes. They were codified by scholars belonging to a British school of thought, A. Pigou being one of them (Pigou, 1932). He suggested that transport taxes should be viewed as a way of internalizing negative externalities that occur in the process of automobile use. In this case, the size of transport taxes should reflect the tax price of the negative external effects so that the car owner pays for them with his money. As a result of the research, the scholars built equations that make it possible to calculate negative externalities associated with $\mathrm{CO} 2$ emissions, road wear, noise, additional road incidents etc. (De Maio \& Vitetta, 2015).

Both approaches are embodied in the system of transport taxes in Europe (Spending on Transport Infrastructure, 2013). The system includes motor vehicle sales taxes, so-called fixed taxes, and use taxes that depend on the intensity of car use, that is, they are in direct proportion to the negative impact caused. The system of fixed taxes is built upon the principles proposed by representatives of École Nationale des Ponts et Chaussées. Variable transport taxes are based on the approaches elaborated by Pigou - that of the reciprocity of harm (predominantly environmental harm) (Heine, Norregaard \& Parry,2012).

\section{Methodology}

The purpose of the analysis is to identify the factors that have an influence on the size of vehicle taxes and other levies in the European Union and Russia, and to establish a correlation between the levies and the state of road infrastructure in the countries.

The primary research methods are analysis, synthesis, comparative analysis and the analogue method.

In order to assess the tax burden on car owners, account is taken of all types of taxes and levies that are paid at 
the moment of purchase and throughout ownership. All types of vehicle taxes are grouped into fixed and variable taxes, and tax revenue designation for each group of taxes is identified. For the purposes of comparative analysis of taxes. factors need to identified that influence the size of each group of taxes.

The countries that were chosen for analysis have different car ownership rates and differ in the state of their road infrastructure, geographic conditions and climate. These are Cyprus, Denmark, France, Germany, Italy, Luxemburg, and the Netherlands. To ensure a broader coverage of vehicles, we suggest conducting a comparative analysis of the calculated tax burden in the cost of vehicles of different categories (small economy car; mid-sized car, and premium car). The burden of fixed vehicle taxes is calculated as their share in the cost of a car. The burden of variable vehicle taxes is calculated as their share in the cost of fuel, since it is fuel that reflects the intensity of car use. The approach makes it possible to obtain comparable relative values of the tax burden on car owners who use their vehicles with varying intensity.

The values obtained for the European countries are compared with those for Russia. The comparative analysis of the factors underlying vehicle taxes in the countries that have been most successful in developing road infrastructure enables one to apply their experience to constructing transport taxation systems in other countries, their specific features being taking into account, of course.

\section{Results and Discussion}

\subsection{Analysis of fixed taxes in the EU and Russia}

The objective of analysing fixed taxes is to produce a broad assessment of the tax burden on car ownership. Fixed taxes are levies that are paid once when a vehicle is purchased and then on a regular basis regardless of how often the vehicle is used. The size of the taxes determines the affordability of cars. Fixed vehicle taxes are therefore a tax price that is paid for owning a vehicle. In Russia, fixed transport taxes include value added tax (VAT), the stamp fee on the purchase of a vehicle, registration fees, the recycling fee, and annually paid vehicle tax.

Table 1: Factors affecting the size of fixed taxes (cross-country comparison).

\begin{tabular}{|c|c|c|c|c|}
\hline \multirow{2}{*}{ Country } & \multirow{2}{*}{ VAT, $\%$} & \multicolumn{2}{|l|}{ Registration fees } & \multirow{2}{*}{$\begin{array}{l}\text { Recurrent taxes (vehicle } \\
\text { taxes paid by owners) }\end{array}$} \\
\hline & & Registration tax & Registration fee & \\
\hline Cyrpus & 15 & Engine capacity, $\mathrm{CO}_{2}$ emissions & Engine capacity & Engine capacity \\
\hline Denmark & 25 & Price and tech specs & Flat & Fuel consumption \\
\hline France & 19.6 & $\mathrm{CO}_{2}$ emissions, fiscal horsepower & Flat & Fixed \\
\hline Germany & 19 & None & Flat & $\begin{array}{l}\text { Engine capacity }+\mathrm{CO}_{2} \\
\text { emissions }\end{array}$ \\
\hline Italy & 20 & Engine power & Flat & $\begin{array}{l}\text { Kilowatts and European } \\
\text { emission standard }\end{array}$ \\
\hline Luxemburg & 15 & None & Flat & $\begin{array}{l}\mathrm{CO}_{2} \text { emissions+ цена + } \\
\text { fuel type }\end{array}$ \\
\hline Netherlands & 19 & $\mathrm{CO}_{2}$ emissions, price, fuel type & Flat & Weight + fuel type \\
\hline Russia & 18 & $\begin{array}{l}\text { There is no registration tax as such in Russia, but there are excise } \\
\text { duties and a recycling fee. The excise duties depend on horsepower, } \\
\text { while the recycling fee is based on car age and engine capacity. }\end{array}$ & Flat & Engine power + price \\
\hline
\end{tabular}

The size of fixed taxes in different countries depends on the technical characteristics of the car that determine its capability to have a negative impact on the road network and environmental factors. The technical characteristics that are usually used for calculating the tax rate are engine capacity and engine horsepower as well as $\mathrm{CO} 2$ emissions (Zahedi \& Cremades, 2012).

In general, the structure of the Russian system of fixed transport taxes matches the European model, one exception being registration taxes because there is no such tax, but there is an equivalent in the form of an excise duty that is paid upon the purchase of a car, and a recycling fee (Mayburov \& Leontyeva, 2014).

We shall calculate the amount of fixed taxes for three types of automobiles: the Fiat 500 (a small economy car with a $85 \mathrm{hp}$ engine); the Ford Fiesta (a mid-sized car with a $120 \mathrm{hp}$ engine), and the Audi A6 (a premium car with a $177 \mathrm{hp}$ engine). For the purposes of the calculations we will convert the prices to euros at the exchange rate of R68.46. In order to calculate the recurrent (vehicle) tax we used tax rates that were effective in Moscow in 2015. The total amount of fixed transport taxes is shown in Table 2. It also shows some qualitative indicators that characterize the process of owning a car (Road StatisticsYearbook, 2016). 
Table 2: Tax burden on car ownership.

\begin{tabular}{|l|c|c|c|c|c|}
\hline Country & $\begin{array}{c}\text { Passenger car } \\
\text { density per network } \\
\text { length }\end{array}$ & $\begin{array}{c}\text { Road network } \\
\text { length, thousand } \\
\mathrm{km}\end{array}$ & $\begin{array}{c}\text { Share of new (less than 5 } \\
\text { years old) cars in total car } \\
\text { fleet, } \%\end{array}$ & $\begin{array}{c}\text { Share of taxes paid upon } \\
\text { purchase of car in its } \\
\text { price, } \%\end{array}$ & $\begin{array}{c}\text { Share of recurrent } \\
\text { taxes in car price, } \\
\%\end{array}$ \\
\hline Cyprus & 0.05 & 9.8 & 19.2 & $14-23$ & $0.2-0.6$ \\
\hline Denmark & 29 & 74.1 & 41.2 & $115-165$ & $0.5-2.3$ \\
\hline France & 31 & $1,065.6$ & 33.9 & $17.6-18$ & $0.5-1.0$ \\
\hline Germany & 65 & 230.5 & 33.6 & 16 & $0.1-2.0$ \\
\hline Italy & 144 & 253.7 & 32.3 & $19-21.5$ & $1.0-1.6$ \\
\hline Luxemburg & 125 & $2,880.0$ & 50.6 & 13 & $0.2-0.5$ \\
\hline Netherlands & 55 & 138.2 & 29.8 & $31-60$ & $2.3-5.0$ \\
\hline Russia & 40 & $1,038.0$ & 27.4 & $17.5-19$ & $0.2-0.4$ \\
\hline
\end{tabular}

The total amount of taxes paid by buyers of new cars in Russia matches that in the developed European countries and is even higher in some cases (e.g., compared to Germany, Luxemburg). It is remarkable that in Denmark and the Netherlands auto sales taxes are considerably higher than in all other countries. Luxemburg charges the lowest tax on the purchase of cars. As a result, it has the largest share of new cars in the total car fleet. In Denmark, the amount of taxes to be paid upon the purchase of car is the highest and even exceeds the price of the car itself. As a result, the country has the lowest passenger car density per network length.

The level of recurrent taxes in Russia is slightly lower than the European average, but it does not stray much from the general line of recurrent transport taxation. The Netherlands has the highest level of recurrent taxes. One can also identify a common trend: the higher the engine power, the higher recurrent taxes.

One can therefore identify two types of effects that fixed transport taxes produce in Russia. First of all, buying a new car in Russia is restricted by a rather high level of fixed taxes (included in the price of the car). Given the insufficient infrastructure (compared to the European countries), this hinders the grown of the car ownership rate. Such an effect could be interpreted as a positive one because it makes it possible to reduce the demand for trips by car and ease traffic congestion.

Second, the high rate of fixed taxes leads to the "ageing" of the passenger car fleet. The share of new cars in Russia is the lowest when compared to other European countries. It has to be noted, though, that another factor contributing to the situation is lower incomes of people in Russia that make it difficult for car owners to regularly replace their obsolete vehicles with newer ones. This effect should be viewed as a negative one because older cars are more polluting.

\subsection{Analysis of variable taxes in the EU and Russia}

The objective of analyzing variable taxes is to produce a broad assessment of the tax burden on the process of using a vehicle. The payment of the taxes is viewed as the price paid for using the road network. In Russia, variable taxes include fuel excise duties. Their main purpose is to regulate the use of vehicles.

The level of variable taxes is pretty much the same across the European countries and is rather high, making up around 30 to 40 percent of the price of fuel (Environment at a Glance, 2015). At the same time, those who drive cars with diesel engines face less tax than those who use vehicles with petrol engines.

Table 3: Prices of fuel and fuel (variable) taxes.

\begin{tabular}{|l|c|c|c|c|c|}
\hline \multirow{2}{*}{ Country } & \multirow{2}{*}{$\%$ of petrol fuel engines in total new registration } & \multicolumn{2}{|c|}{ Fuel price, euros } & \multicolumn{2}{|c|}{ Fuel taxes (\% of price) } \\
\cline { 3 - 6 } & & Petrol & Diesel & Petrol & Diesel \\
\hline Cyprus & 80 & 1.205 & 1.306 & 30.7 & 26.5 \\
\hline Denmark & 45 & 1.584 & 1.422 & 36.2 & 27.1 \\
\hline France & 33 & 1.491 & 1.368 & 41.5 & 31.8 \\
\hline Germany & 51 & 1.507 & 1.399 & 44.0 & 33.4 \\
\hline Italy & 46 & 1.674 & 1.654 & 39.4 & 31.5 \\
\hline Luxemburg & 27 & 1.289 & 1.202 & 36.8 & 26.4 \\
\hline Netherlands & 71 & 1.623 & 1.375 & 45.1 & 30.9 \\
\hline Russia & 93 & 0.558 & 0.520 & 10.9 & 7.7 \\
\hline
\end{tabular}


Additionally, the price of diesel is usually lower than that of petrol. The bigger the difference in the fuel prices and the share of variable (fuel) taxes in the price, the more distinct is consumers' preference when buying a car. For example, in the majority of the countries in question the population favors diesel cars due to the lower price of diesel fuel and a lower share of taxes in the price.

In Russia, variable transport taxes create a considerably smaller burden - it is about three times smaller than in Europe. Fuel prices, too, are 150 percent lower in Russia than in Europe. Consequently, the use of cars is relatively tax free compared to the European countries. An insignificant gap in the prices for petrol and diesel results in consumers' preference for petrol cars. The share of cars with petrol engines in car sales in Russia is much higher than in any European country and reaches 93 percent. This effect should also be viewed as a negative one because petrol engines are less environmentally friendly.

Broadly speaking, congestion charges and tolls for using sections of roads, tunnels, driving through conservation areas or driving into urban areas can also be classified as variable transport taxes. Tolls vary greatly from country to country.

The average charge per $\mathrm{km}$ of the road network per year is a universal indicator that, on the one hand, characterizes the price of using the road infrastructure and, on the other hand, it takes into account the share of toll roads in the network.

Table 4: Toll revenues in EU and Russia.

\begin{tabular}{|l|c|c|c|}
\hline Country & Road network length, thousand $\mathrm{km}$ & Toll revenue, million euros & Average toll rate per km per year \\
\hline Cyprus & 9.8 & 0 & 0 \\
\hline Denmark & 74.1 & 537 & $7,246.9$ \\
\hline France & $1,065.6$ & $9,222.4$ & $8,654.7$ \\
\hline Germany & 230.5 & 4,460 & $19,349.4$ \\
\hline Italy & 253.7 & $5,176.9$ & $20,405.6$ \\
\hline Luxemburg & $2,880.0$ & 0 & 0 \\
\hline Netherlands & 138.2 & 27.7 & 200.4 \\
\hline Russia & $1,038.0$ & 21.9 & 21.1 \\
\hline
\end{tabular}

\section{Conclusion}

The analysis makes it possible to identify three different approaches to regulating motor vehicles in the EU countries. A number of countries (Cyprus, Luxemburg) keep both fixed and variable transport taxes low. By doing so, they create favorable conditions for purchasing and using passenger cars. These are usually countries with a small territory or island countries. Some countries (Denmark, Netherlands) have a very high level of fixed and recurrent transport taxes, thus restricting both the purchase and use of motor vehicles. Other countries (France, Italy) have relatively low fixed transport taxes, but charge high variable taxes, which does not restrict the purchase of cars, but discourage people from using them a lot. In Russia, the system of transport taxes lacks logic. The level of fixed taxes that is rather higher for Russia generates two effects: it hinders the growth of car ownership and preserves the negative structure of the car fleet. The low level of variable taxes (fuel tax and tolls) encourages the intense use of passenger cars. The approach will spur further growth of car ownership rates in Russia, making people car dependent. A reform of variable transport taxes is needed to regularly increase them. Such an increase should also be accomplished by regularly increasing fuel excise duties and introducing congestion charges and toll charges on more roads, bridges, tunnels, and conservation areas. The case of the European countries shows that it will take plenty of time and consistent effort for people to get used to higher variable taxes and that the process should go in parallel with improving the quality of public transport and developing the road network.

\section{References}

Baumol, W. (1972). On taxation and the Control of Externalities. The American Economic Review, 62 (3), 307-322.

De Borger, B. \& Mayeres, I. (2007). Optimal taxation of car ownership, car use and public transport: insights derived from a discrete choice numerical optimization model. European Economic Review, 51, 1177-1204.

De Maio, M.L. \& Vitetta, A. (2015). Route choice on road transport system: a fuzzy approach. Journal of Intelligent and Fuzzy System, 28(5), 2015-2027.

Derycke P.H. (1998). Road pricing - Analysis \& policies (A historical perspective). Researches Economigues de Louvain, 64 (1), 63 -74. 
Environment at a Glance - 2015. OECD Indicators. (2015). OECD Publishing, Paris.

Europe in figures - Eurostat yearbook. (2016). Eurostat Statistics Explained, Luxemburg.

Heine, D., Norregaard, J. \& Parry, I. (2012). Environmental Tax Reform: Principles from Theory and Practice to Date. IMF Working Paper.

Litman, T. (2009). Transportation Cost and Benefit Analysis: Techniques, Estimates and Implications. Executive Summary. (2nd ed.). Victoria Transport Policy Institute, Victoria.

Levinson D. (2010). Equity Effects of Road Pricing: A Review, Transport Reviews, Vol.30 (1) (January), pp.33-57.

Mayburov, I. \& Leontyeva, Y. (2014). Reducing the negative impact of motor transport on the environment: prospects for the use of fiscal instruments in Russia. Proceeding of the Conference Air Pollution 2014, eds. C.A. Brebbia, WIT Transactions on Ecology and the Environment, WIT Press, UK, 186.

Pigou, A. (1932). The Economics of Welfare. (4th ed.). London: Macmillan.

Road StatisticsYearbook - 2016. (2016). European Union Road Federation. Brussels. Belgium.

Russo, F., Rindone, C., D’Agostino, P., Lanciano, C. \& Scattarreggia, T. (2015). A city logistic system for long distance freight transport provisioning. Proceeding of the Conference Urban Transport XXI 2015, eds. C.A. Brebbia, WIT Transactions on the Built of Environment, WIT Press, UK, 146, 279-291.

Spending on Transport Infrastructure 1995-2011: Trends, Policies, Data. (2013). OECD Publishing, Paris.

Zahedi, S. \& Cremades, L. (2012). Vehicle taxes in EU countries. How is fair is their calculation? Proceedings of the XVI Congreso Internacional de Ingeniería de Proyectos, Valencia, Espana.

Vuchic, V.R. (1999). Transportation for Livable Cities. New Brunswick, Center for Urban Policy Research, 1999. 